\title{
Sosyal Medya Haberciliğinde Etik: Instagram Hesapları Üzerine Bir İnceleme
}

\author{
Mustafa TEMEL* \\ Burak SOMUNCU** (D) \\ Bünyamin GÜLTEKİN** (D)
}

ÖZ

İnternet teknolojilerinin gelişmesi haberleşme alanında birçok yeniliği de beraberinde getirmiştir. Bu yenilikler arasında ise bireylerin içerik (haber, bilgi) üreticisi olması ve bununla birlikte sosyal medya ağlarını haberleșme sürecinde aktif olarak kullanması en dikkat çekici unsurlardandır. Yeni medya ortamının sunmuş olduğu hız, interaktif özellik, ücretsiz içerik, denetimden uzak olma gibi özellikler sebebiyle sosyal medya araçlarının tercih edilebilirliği artmıș, bu ortamlar aynı zamanda yeni haberleşme ağlarını ortaya çıkarmıştır. Fakat sosyal medya ağları üzerinden gerçekleştirilen haberleşme pratikleri, habercilik alanındaki var olan etik problemleri de sürdürmüş hatta dijitalleşmenin olanakları sebebiyle etik problemlerin artışına sebep olmuştur.

$\mathrm{Bu}$ araştırmanın amacı da sosyal medya haberciliğindeki etik problemleri incelemektir. Instagram örneğinde sosyal medya haberciliğindeki etik problemleri tespit edebilmek amacıyla örneklem olarak seçilen Instagram hesaplarının biçimsel ve içerik özellikleri incelenmiştir. Tespit edilen hesaplar etik problemlerden hareketle oluşturulan değerlendirme kriterleri çerçevesinde ele alınmıştır. Dolayısıyla literatürdeki geleneksel medya ve etik konularına kıyasla, sosyal medya aracılığı ile haberleşme ve etik meselesi konusunu ele alan bu çalışmada içerik analizi yöntemi kullanılmıştır. Bu bağlamda yapılan araştırma sonucunda, örneklem olarak alınan haber/medya şirketi etiketi ile Instagram üzerinden paylaşım yapan hesapların habercilikte uyulması gereken etik unsurlara yeteri kadar dikkat etmediği özellikle kaynak, güvenilirlik konularındaki etik problemleri fazlaca ihtiva ettiği tespit edilmiștir.

Anahtar Kelimeler: Medya ve Etik, Haber, Yeni Medya, Sosyal Medya, Instagram

\section{Ethic in Social Media Journalism: A Review on Social Media Accounts}

\begin{abstract}
The development of internet technologies has brought many innovations in the field of communication. Among these innovations, the most striking factors are that individuals are producers of content (news, information) and actively use social media networks in the communication process. The preference of social media tools has increased due to the features such as speed, interactive feature, free content, and being uncontrolled by the new media environment and these environments have also created new communication networks. However, communication practices carried out over social media networks have continued the existing ethical problems in the field of journalism and even caused an increase in ethical problems due to the possibilities of digitalization.

The aim of this research is to examine ethical problems in social media journalism. In the example of Instagram, in order to identify ethical problems in social media journalism, the formal and content features of the selected Instagram accounts were examined. The determined accounts were handled within the framework of the evaluation criteria created based on ethical problems. Therefore, in comparison to traditional media and ethical issues in the literature, content analysis method was used in the study dealing with the issue of communication via social media and ethics. As a result of the research conducted in this context, it was determined that the accounts sharing the news / media company tag and the Instagram accounts did not pay enough attention to the ethical elements that should be followed in journalism, and even included ethical problems especially in the issues of source and reliability with digitalization.
\end{abstract}

Keywords: Media and Ethics, News, New Media, Social Media, Instagram

\section{Giriş}

Tarihsel süreçte insanların temel ihtiyaçlarından biri olan haberleşme, iletişim teknolojilerinin gelişimi ile değişime uğramış, güçlenen iletişim araçları ve özellikle gelişen/yaygınlaşan internet ağı ile haberleşme süreci yeni boyutlara taşınmıştır. Teknolojik gelişmelerle birlikte iletişim pratikleri de değişmiş, bireyler haber üretim ve tüketim sürecinde aktif hale gelmişlerdir. Küreselleşme ile genişleyen bilgi ve iletişim ağ1

\footnotetext{
* Dr. Öğr. Üyesi., Erciyes Üniversitesi, mustafatemel@erciyes.edu.tr

** Öğr. Gör., Adana Alparslan Türkeş Bilim ve Teknoloji Üniversitesi, bsomuncu@atu.edu.tr

*** Öğr. Gör., Adana Alparslan Türkeş Bilim ve Teknoloji Üniversitesi, bgultekin@atu.edu.tr Makalenin Gönderim Tarihi: 14.12.2020, Makalenin Kabul Tarihi: 08.03.2021
} 
da bireylerin bu konumunu güçlendirmiş, bireylerin haberleşme ve bilgi edinme isteğini artırmıştır. Yerel ilgiler ile birlikte küresel çapta yaşanan gelişmelere olan ilgi de temel öğrenme ihtiyacına eklemlenmektedir. $\mathrm{Bu}$ bağlamda, elde edilen bilgilerin/haberlerin çeşitlenerek artması da bilginin/haberin önemini kuvvetlendirmektedir.

Çeşitli fikirleri dolaşıma sokarak toplumun ortak paydada buluşmasını amaçlayan haberler, bilgi sağlama, güdüleme, tartışma ortamı oluşturma gibi işlevlerinin yanında siber uzamda oluşturulan yeni kamusal alanda, eğlenme ve öğrenme alışkanlıklarını da şekillendirmektedir. Haberleşmenin değişen bu yapısı, sosyal medya ile birlikte farklı bir görünüm kazanmıştır. Sosyal medya araçları ile haber üretim ve tüketim pratikleri değişmiş, bireyler sosyal medyayı haberleşme sürecinde kullanarak, geleneksel gazeteciliğin tekelini ve haber dağıtımındaki hegemonyasını kırmıştır. Bu süreçte, kullanıcıların sosyal medya platformlarının kişiselleştirme özelliğinden hareketle, ilgi alanlarına göre içerik tercih etmeleri, yine ilgi alanlarına göre içerik üretmeleri/paylaşmaları, beğenme ve yorumlama eylemlerinde bulunmaları sosyal medya araçlarının haberleşme sürecinde yoğun kullanılmasını beraberinde getirmiştir (Çetinkaya, 2019; 7).

Yeni medya kullanıcılarının sadece tüketici değil aynı zamanda üretici olduğu, internet ağları üzerinden bilgi akışını son derece hızlı bir şekilde sağlayabildiği ve birbiriyle iletişime geçebildiği bu süreçte sosyal medya platformları bilginin paylaşılması ve yayılmasında önemli imkânlar sağlamaktadır. Fakat sosyal medya ağları üzerinden haberlerin kolay bir şekilde üretilip, ücretsiz bir şekilde, hiçbir denetim olmadan yayımlanması bir takım problemleri de beraberinde getirmiştir.

Literatürde sosyal medya araçlarının (özellikle Facebook, Twitter örnekliğinde) bilgi edinme/haberleşme sürecindeki rolünü ve dijitalleşme ile dönüşüme uğrayan habercilik pratiklerini ele alan çalışmalara rastlamak mümkündür. Fakat medya/yeni medya ve etik ilişkiselliği doğrultusunda dijitalleşme sürecinde karşılaşılan etik problemleri konu alan çalışmaların az olması ve sosyal medya haberciliğinde etik konusunu Instagram örneğinde tartışan çalışmanın olmaması dikkat çekmektedir.

$\mathrm{Bu}$ perspektifte, sosyal medya üzerinden yapılan habercilik faaliyetini etik meseleler üzerinden sorgulamayı amaçlayan çalışmada; öncelikli olarak yeni medya kavramı, sosyal medya haberciliği ve habercilikteki etik problemler doğrultusunda kavramsal çerçeve oluşturulmuştur. Dijitalleşme sürecinde ve sosyal medya haberciliğinde dikkat edilmesi gereken etik problemler ile ilgili oluşturulan teorik alt yapı ile birlikte; sosyal medya haberciliğinde etik unsurların kullanımını ölçebilmek amacıyla, son yıllarda kullanım oranı artan ve içerik üretiminde/paylaşımında herhangi bir kontrol mekanizmasının olmadı̆̆ı Instagram uygulamasında belirli bir kuruma ve işletmeye bağlı olmayan veya bu konular ile ilgili bir bilginin teyit edilemediği dört Instagram hesabı içerik analizi yöntemiyle incelenmiştir.

\section{Sosyal Medya ve Habercilik}

Yeni medya kavramı, iletişim becerilerimizi artıran cihazları, teknolojik imkânlar kullanılarak oluşturulan içerik ve pratiklerin etrafında şekillenen sosyal düzen ve örgütlenmeleri kapsamaktadır (Binark, 2014, s. 15). Geleneksel medyadan farklı bir şekilde yeni medya, sayısal medyayı, internet ağlarını ve sosyal iletişim medyasını nitelemek için kullanılmaktadır (Binark, 2014, s. 15). Bu anlamda içinde birçok yeniliği barındıran yeni medyadaki 'yenilik' mesajdan ziyade, mesajın paylaşılmasını sağlayan ortamın yeniliklerinden kaynaklanmaktadır (Öztürk, 2015, s. 289).

Yeni medyanın bir diğer 'yeniliği' teknolojilerin iletişim alanında aktif bir şekilde yer alması ve sunulan içeriğin çoklu ortamlar aracılı̆̆ıyla çeşitlenerek yayımlanmasıdır (Timisi, 2003, s. 80). Aynı zamanda multimedya da denilen çoklu ortamlar, yeni medyanın çeşitlendiği anlamına gelmektedir. Görüntü, yazı ve ses gibi ortamların bir aradalı̆̆ı bu özelliği meydana getirmektedir (Dilmen, 2007, s. 115).

Yeni medya dijitallik, etkileşimlik, multimedya biçimselliği ve kullanıcı türevli içerik üretimi, hipermetinsellik, yayılım ve sanallık gibi özellikleri ile geleneksel medyadan ayrılmaktadır (Bayraktutan, 2012, s. 250; Binark ve Löker, 2011).

Kullanıcı merkezli olan, farklı bilgi kaynaklarına anında erişimi daha kolay hale getiren, kişiye özel yayıncılı̆̆a imkân veren yeni medya (Timisi, 2003, ss. 82-83) araçları haberleşme sürecini önemli ölçüde değiştirmiştir. Merkezîleşmeyi de ortaya çıkaran yeni medya sınırsız, açık, ağ tabanlı bir etkileşimi de beraberinde getirmiştir (Aydoğan \& Kınık, 2012, s. 59) 
Görse1 1. Türkiye'deki Sosyal Medya Kullanım İstatistikleri ve Sosyal Medya Kullanıc1 Sayllar1

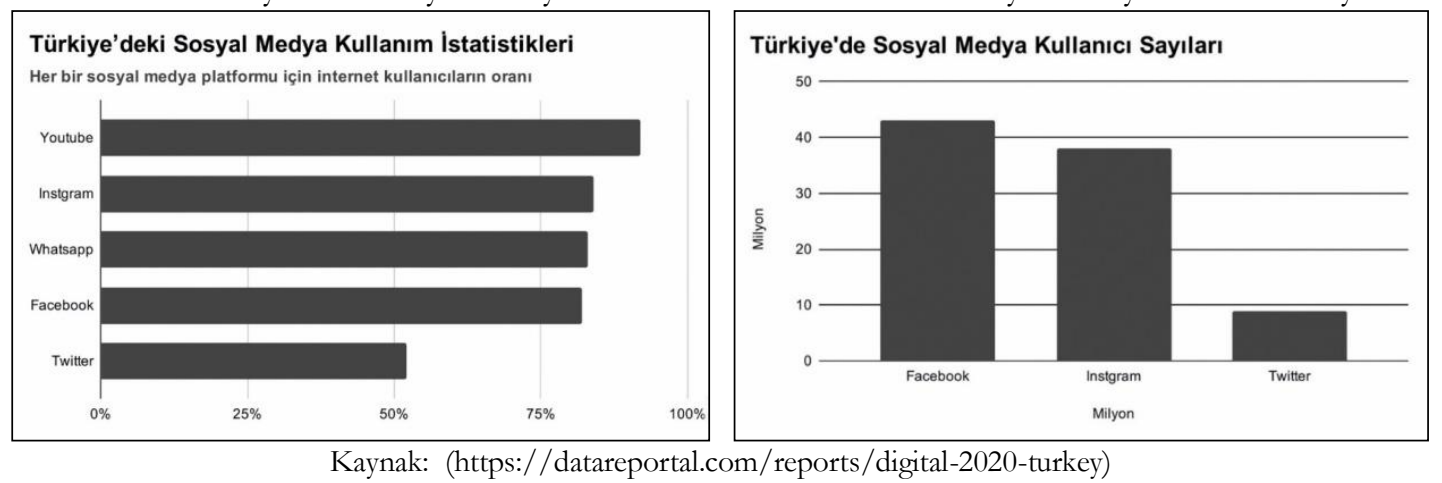

Geçmişte MMS ve SMS teknolojisini sıklıkla kullanarak haberlerini okuyucularına aktaran medya, 2000 'li yıllar ile birlikte çevrimiçi sosyal medya platformlarına yönelmiştir. İnternet üzerinden kullanıcılara profil oluşturma ve içeriği paylaşma ve geliştirme imkânı veren erişilebilir platform özelliğine sahip olan sosyal medya (Kennedy, 2015, s. 11) habercilik pratiklerini de değiştirmiştir. Sosyal medya, hem gazeteciliğin yapıldığ yeni bir ortam hem de gazeteciler için bir haber kaynağı olarak kullanılmaya başlanmıştır. Bloglar, sosyal ağlar, formlar, web siteleri gibi araçlarla okuyucu/izleyici arzu ettiklerinde içerik üreticisi olabilmiştir (Kurt, 2014, s. 824). Bu uygulamalar ile her vatandaş istediğinde interaktif bir şekilde gazetecilik yapabilir hale gelmiş, kendi medyasını oluşturabilmiştir.

Sosyal medya uygulamalant haberleşme sürecinde iki önemli işlevi yerine getirmektedir. Birincisi sosyal medya içerik üretme açısından bir özgürlük tanımaktadır. Bu sebeple birey haber üreticisi konumuna gelmiş ve bu durum profesyonel gazetecilik mesleğiyle uğraşanlar ile haberin tüketicisi olan bireyler arasındaki sınırı kaldırmıștır. İkincisi ise kullanıcılar, bireysel sosyal medya hesapları ile istedikleri her konuda görüş beyan edip diledikleri konularda yazabilmektedirler. Bu imkânların tamamı yurttaş gazeteciliği kavramının oluşmasına nedsen olmuştur (Özcan, 2019, s. 8). Tanımlaması güç olan yurttaş gazeteciliği ise geniş bir çerçevede haber toplama, üretme ve dolayıma sokma safhalarında, gazetecilikle profesyonel olarak uğraşmayan vatandaşların, mevcut teknolojik imkânlar dâhilinde yer aldığ1, yeni bir gazetecilik pratiği olarak tanımlanabilir (Devran \& Özcan, 2017, s. 154).

Gazetecilik çerçevesinde sosyal medya ele alındığında ön plana çıkan bir başka etki ise sosyal medya kullanıcılarının içeriklerini ücretsiz, özgürce, herhangi bir filtreleme ya da eşik bekçisi kontrolü olmaksızın yayınlayabilme olanağına sahip olmasıdır (Taşkıran \& Kırık, 2016, s. 228). Medya profesyonellerince hazırlanan haberlerde mutlaka bir iş akışı ve kontrol mekanizması mevcuttur. Haberler, kontrol ve onay aşamasından geçmektedir. Sosyal medya da ise bir yurttaş tarafindan hazırlanan, haber, bilgi vb. içerik hiçbir filtreleme, onay ve düzeltmeye maruz kalmadan, teyit edilmeden yayımlanabilmektedir.

Özetle, günümüzde teknolojik altyapı, dijitalleşme ve iletişim ortamlarının sağlamış olduğu imkânlar ile sosyal medya haberciliği yaygınlaşmakta, profesyonel medya kuruluşlarının yanı sıra yurttaş gazeteciliği yapan kişiler/kurumlar, ücretsiz bir şekilde oluşturdukları sosyal medya hesapları ile haber üretim ve dağıtım gerçekleştirebilmektedir.

\section{Habercilikteki Etik Sorunların Dijitalleşme ile Artan Görünümleri}

TDK'ya göre etik "ahlaki, ahlakla ilgili, töre bilimi, çeşitli meslek kolları arasında tarafların uyması veya kaçınması gereken davranışlar bütünü” olarak tanımlanmaktadır (Türk Dil Kurumu Sözlükleri, 2020). Etik, birlikte yaşayan insanların, davranışlannı kendilerine göre düzenlediği ilke ve kurallar sistemi ya da dizisi anlamına gelmektedir (Bayrak, 2017, s. 38). Köken itibariyle Yunancadan gelen etik kavramı, iyi ve kötü ile ilgili ahlaki yarg1ları ifade etmektedir (Uzun, 2007, s. 11).

Mesleki etik ise bir meslekte doğru ve yanlış unsurları belirleyen, meslek ile ilgili davranış kuralları oluşturan ve mesleği uygulayan kişilerin bu kurallara uymasını zorunlu kılan ilkeler anlamında kullanılmaktadır. Bu bağlamda halkın doğru haber alması ve bilgi edinmesi için faaliyet gösterilmesi de gazeteciliğin temel doğru davranış kuralları arasındadır. Her meslekte olduğu gibi iletişimle ilgili 
mesleklerde de etiksel ilke ve değerlerin belirlenmesi ve yaşama geçirilmesi, kurumun kendi kendini düzenlemesiyle gerçekleşir (Uzun, 2007, s. 18). Bu bağlamda ulusal ve uluslararası cemiyetler, basın konseyleri, dernekler, yayın kuruluşlan ve Türkiye'deki Basın İlan Kurumu ve RTÜK gibi yetkilendirilmiş basın kuruluşlarının metinlerinde gazetecilerin doğru davranış kurallarını Türkiye Gazetecileri Hak ve Sorumluluk Bildirgesi örnekliğinde şu şekilde özetlemek mümkündür (www.tgc.org.tr):

-Haber ve yorum ayrımı yapilmalıdır.

-Görsel unsurların gerçeği yansıtması, manipüle amaçlı kullanılmaması gerekir.

-Reklam amaçlı içerik kullanımında dikkat edilmeli, haber/bilgi ayrımı yapılmalıdır.

-Gazeteciler toplumsal sorumluluk bilinciyle hareket etmeli ve mesleki kimliğe zarar verecek eylemlerden kaçınmalıdır.

-Gazeteciler suç unsuru taşıyan söylem ve davranışlardan kaçınmalıdır.

-İçerik üretim ve yayım sürecinde telif haklarına dikkat emelidir. Kaynak mutlaka belirtmelidir.

Gazeteciliğin/haberciliğin doğru davranış kurallarını özetleyen bu etik meseleler ile birlikte özellikle hızla yaygınlaşan dijitalleşme sonucu haberleşme/bilgi aktarım sürecinde, bu unsurlara ek olarak bilginin doğruluğu ve gerçekliği gibi bazı etik problemler/tartışmalar yeniden gündeme gelmiştir. Sosyal medya mecralarında doğruluğu, gerçekliği ve kaynağı belirsiz olan içeriklerin kolayca paylaşılabilmesi bilginin doğruluğunu ve güvenilirliğini tehlikeye sokmuştur. Tahrip edilmiş ya da çeşitli manipülasyon yöntemleriyle üzerinde oynanmış fotoğraf ve görseller bu sosyal medya ağları üzerinden paylaşılarak, ülkelerin ya da dünyanın gündeminde çatşsma ve panik yaratabilen bir boyuta ulaşmışır (Erdoğan, 2014, s. 81). Bu araçlarda eşik bekçiliğinin de işlevsellik gösterememesi sosyal medya üzerindeki haberlerin gerçekliğini ve güvenirliliğini tartışmalı hale getirmiştir (Aydın \& Yazıcı, 2020, s. 117).

Dolayısıyla habercilikte süregelen etik problemlerin dijitalleşme sonucu yeni boyutlarıly birlikte daha önemli bir sorun alanı haline geldiğini söylemek mümkündür. Bu bağlamda konu ile ilgili yapılan araşturmalarla tespit edilen, yeni medyanın eklemlendiği ve sosyal medya haberciliğinde daha fazla görünür olabilen etik sorunları şu şekilde belirtmek mümkündür (Binark \& Bayraktutan, 2013, s. 39; Erdoğan, 2014, s. 87; Kalan, 2016, s. 78):

“Özel Yaşamın Gizliliği: Özel yaşamın gizliliği, yeni medya ortamlarında, özelliklede sosyal medyada çeşitli şekillerde ihlal edilebilmektedir.

Telif-Patent Hakları: Bir kişi ve kuruluşun emeği ile kazanç elde etmek haksız kazanç ve korsanlık olarak tanımlanmaktadır. Fikir hırsızlığı, tasarım hırsızlığı, fotoğraf hırsızlığı, vb. bu ihlal kapsamında değerlendirilebilmektedir.

Kaynak Gösterilmemesi: Yeni medya ortamında alıntılama ve kopyala yapıştır olaylan artmıştır. Başka birinin çalışmasını izinsiz ve kaynak göstermeden kopyalama etik bir problemdir.

İçeriklerin Teyit Edilmeden Yayımlanması: Yeni medya gazeteciliğinde, çevrimiçi içeriğin çok çabuk bir şekilde yayımlanması, adil, doğru ve önyargısız çalışma anlayışına zarar verebilmektedir. Online ortamda üretilen ya da elde edilen bilgi (fotoğraf, haber, video, ses vb.) medya profesyonelleri tarafindan kontrol edilmelidir. Hıza dayalı bir ortam olan internet, kolaylikla hatalara yol açabilmektedir

Kişisel Verilerin Güvenirliğinin Sağlanamaması: Yeni medya ile birlikte artan tecimsellik kişisel verilerin güvenliğinin sağlanması gerekliliğinin ortaya koymaktadır. Bireyin yeni medya ortamlarında paylaştı̆̆ bilgiler, bir veri oluşturmaktadır. Bu verilerin güvenliği ve saklanması önem arz etmektedir.

Veri Madenciliği: Veri madenciliği çeşitli bilgi parçaları arasında ilişkiler kurulmasıdır. Yeni medya ortamlarında, kullanıcılar tarafindan bırakılan dijital izler, veri madenciliği ile anlamlı bir şekilde eşleştirilerek kullanılmaktadır. Örneğin bir internet sitesi Facebook üzerinden beğen butonu koyarak kişilerin Facebook sayfasına buradaki kişisel iletişim bilgilerine ve arkadaşlarının sosyal ağına ulaşmaktadır.

Haber ve Ticari Enformasyonun Sınırlarının Belirsizleşmesi: Yeni medya gazeteciliğinde haber içeriği ve reklam arasındaki sınırların ortadan kaldırılması etik açıdan bir problemdir. Haber ile reklam alanlarının iç içe girmesi ve birbirinden ayrılmaması, 
haberlere eklenen linkler ile reklam sayfalarına bağlantı verilmesi, okurlarda güveni azaltmaktadır.

Yeni Medya Ortamındaki Yoğun Reklam İçeriği: Web sayfalarında yer alan yoğun reklamlar ve linkler, ulaşmak istenilen içerikten çok daha fazla yer kaplayarak, dikkat dağıtarak yorucu olmaktadır. Web sayfalarında ve sosyal medyada haberler neredeyse reklamın bir parçası olmuş gibidir.

Yanıltıcı Etiketleme ve Başlıklandırma: Web sayfalanı ve sosyal medya mecralan kullanıcıların reklama tıklamasını sağlamak için, bilerek yanlış ve sansasyonel etiketleme ve başlıklandırmalara başvurmaktadır.

Nefret Söylemi: Yeni medya, gündelik yaşamın söylemsel pratiklerinde üretilen ve geleneksel medya metinlerinde dolaşıma sokulan nefret söyleminin çok daha kolay bir şekilde yaygınlaşmasına ve sıradanlaşmasına neden olmaktadır.

Bireyin Yeni Medya Ortamında Sadece Tüketici Olarak Konumlandırılması: Bireyin yeni medya ortamında sadece tüketici olarak konumlandırlması, reklam kirliliğini yaratan bir sorundur. Bu ortamda bulunan insanların dijital izleri takip edilerek, ilgi alanlarına göre reklam dayatılması yine etik problemlerden biridir. Kişisel verilerin ticari amaçlı kullanımı sorunu aynı zamanda özel yaşamın gizliliği, veri madenciliği sorunlarıyla da ilișkilidir."

Bütün bunlarla birlikte, birçok kişinin sahte kimlikli kullanıcı hesapları ile içerik üretmesi; bu hesaplarda keyif veya provoke amaçlı sahte/ideolojik paylaşımlarda bulunulması; tıklanma oranını artırma gayesi ile uzmanlıktan uzak bir şekilde aldatıcı ve gerçeği yansıtmayan başlıkların ve bildirimlerin üretilmesi; içeriklerin editöryal süreçten geçirilmeden dolaşıma sokulması; telifsiz bir şekilde kopyala yapışır şeklinde sanal mecralarda içerik paylaşılması dijitalleşme ile görünür olan ve artan etik problemlerdir.

\section{Sosyal Medya Haberciliğinde Etik: Instagram Hesapları Üzerine Bir İnceleme}

\subsection{Araştırmanın Tasarımı}

\subsubsection{Araştırmanın Amacı ve Önemi}

Son yıllarda kullanıcı sayısı artan sosyal medya araçları bilgiye/habere ulaşma sürecinde sıkça kullanılmaktadır. Bu noktada, önemli bir haber/bilgi kaynağı konumunda olan sosyal medya platformlannndaki içeriklerin etik değerlere bağlı bir şekilde üretilmemesi, editoryal kontrol mekanizmasının yokluğu önemli bir sorun alanıdır. Dolayısıyla bu çalışmada da sosyal medya araçları içerisinde önemli bir konuma sahip olan Instagram uygulamasında yer alan haber paylaşım sayfalarının içeriklerinin etik değerler çerçevesinde sorgulanması amaçlanmıştır.

Habercilik alanında uzman/yetkili kişi ve medya kurumlarının dışında, bağımsız bir şekilde haber üretimi/haber paylaşımı yapan Instagram hesaplarının etik ilkeler çerçevesinde değerlendirilmesi, sosyal medya haberciliğinin mevcut durumunu yansitacakttr. Instagram örneği ile sosyal medya haberciliğini etik kurallar çerçevesinde sorgulayan çalışma, medya ve etik tartışmalarına dijitalleşme perspektifinden bakması sebebiyle ayrı bir önem taşımaktadır.

\subsubsection{Araştırmanın Kapsamı ve Sınırlılıkları}

Araştırma kapsamında 2020 yll Ekim ayı içerisinde Boomsocial'da yer alan (sosyal medya takip ve raporlama sitesi/programı) ve basın yayın kategorisindeki haber siteleri sekmesinde sıralanmış olan 112 Instagram hesabı değerlendirilmiştir. Ön değerlendirmenin yapıldı̆̆ bu hesaplar arasında habercilik alanında geleneksel medyada faaliyet gösteren kurumların hesapları ve alan ile ilgili yetkinlik durumu (kurumsallık bilgileri vb.) bulunan Instagram sayfaları yer almamaktadır. Çalışmanın boyutunu aşacak olması sebebiyle, herhangi bir kuruma ve işletmeye bağlı olmayan, kimlik/künye bilgilerinin detaylı bir şekilde belirlenemediği ve habercilik ile ilgili eğitim/uzmanlık durumuna ilişkin bilgilerin rastlanmadığı sayfalar değerlendirilmiştir. Değerlendirme sonucunda Instagram hesapları içerisinde medya/haber şirketi etiketi ile yayın yapan ve araştırmaya imkan tanıyacak içeriklere sahip olan ve en fazla takipçisi bulunan "ankaradasondakikahaberleri”, "adana.haberleri", "samsunmedya", "istanbul.sondakika" erişim adresine sahip dört Instagram hesabı incelenmiştir. 
Ana olgu hakkında bilgi edinmek veya onu anlamak için bireylerin ve araştırma mekânlarının maksatlı bir biçimde seçildiği ve seçim sırasında temel unsurun bilgi açısından zengin içeriklerin seçilmesine imkân tanıması sebebiyle amaçlı örneklem (Creswell, 2019, s. 267; Erdoğan, 2012, s. 210) doğrultusunda seçilen dört Instagram hesabının 19 Ekim 2020 ile 25 Ekim 2020 tarihleri arasındaki paylaşımları incelenmiştir.

\subsubsection{Araştırmanın Yöntemi}

Görsel, işitsel, metinsel her türlü içeriğin önceden belirlenmiş temalar çerçevesinde sistematik olarak incelenmesine imkân tanıyan içerik analizi, içerik iletebilen sözcükler, anlamlar, semboller, düşünceler, temalar, resimler aracılığ 1 ile herhangi bir iletiye, anlama gönderme yapmaya imkân tanır (Geray, 2014, s. 135; Neuman, 2014, s. 466). Bu sebeple, sosyal medya haberciliğindeki etik problemleri tespit edebilmek amacıyla Instagram hesaplarının biçimsel ve içerik yapısı içerik analizi yöntemiyle incelenmiştir. Yukarıda bahsedilen, dijitalleşme ile artan etik problemlerden hareketle oluşturulan kategoriler çerçevesinde yeni bir kategori sistemi/değerlendirme kriteri geliştirilmiştir. Geçerliliğin ve güvenilirliğin sağlanabilmesi amacıyla oluşturulan kategori sistemi ile örneklemde yer alan Instagram hesapları farklı zaman ve mekânlarda doktora yapan iki kişi tarafindan da birer kez kodlanmış ve kodlama sonucunda büyük oranda (\%90 üzeri) benzerlik sağlanmıştur.

\subsubsection{Araştırma Sorular1 ve Değerlendirme Kriterleri}

Sosyal medya haberciliğinde karşılaşılan etik problemleri Instagram hesapları örneğinde tespit edebilmek amacıyla aşağıdaki soruların cevabı aranmıştır:

A.1. Habercilik alanında içerik üreten Instagram hesaplarında yayıncılara ait veriler yer alıyor mu?

A.2. Instagram hesaplanının içerik yapısı nasıldır?

A.3. Sayfalarda yer alan içeriklerin özgünlük durumu ve referans kullanımı nedir?

A.4. Sayfalarda yer alan içeriklerin nitelikleri nelerdir?

Yukandaki araştırma sorulanna cevap bulabilmek amacıyla, Instagram hesapları aşağıda belirtilen ve habercilikteki etik kurallar göz önüne alınarak oluşturulan dört temel değerlendirme kriteri ${ }^{1}$ çerçevesinde incelenmiştir:

1.Sayfaların Yayıncı Bilgileri ve Yapısı: Belirlenen bu kriter ile hesapların kimlik/künye bilgilerinin durumu ve sayfaların fiziki yapısı/özellikleri ölçülmüştür:

1.1.Instagram hesaplarında kimlik ve künye bilgileri yer alıyor mu?

1.2.Hesapların yayın amaçları belirtilmiş midir?

1.3.Sayfaların içerik üretiminde bir kontrol süreci uygulanıyor mu?

1.4.Sayfalar okurların/kullanıcıların yorum yapmasına imkân tanıyor mu?

2.Sayfaların İçerik Yapısı: Sayfalarda yer alan içeriklerin yayınlanma biçimi incelenmiştir:

2.1.Sayfaların içerik paylaşım sayısı ve sıklı̆̆ı nedir?

2.2.Reklam kullanım durumu nedir?

2.3.Hangi tür içeriklere/konulara yer verilmektedir?

3.Sayfalarda Yer Alan İçeriklerin Referans/Özgünlük Durumu: Sayfalarda yer alan içeriklerin referans/uzmanlık/özgünlük durumu ile ilgili sorgulama yapılmıştır:

3.1. İçeriklerde kaynak belirtilmiş mi?

3.2.Etiketleme ve yönlendirme mevcut mu?

3.3. İçeriklerin özgünlük durumu nedir?

4.Sayfalarda Yer Alan İçeriklerin Nitelikleri: Sayfalardaki paylaşımların içerik özellikleri değerlendirilmiştir:

4.1. İçeriklerde haber ve reklam ayrımı yapılmış mı?

4.2.Suç unsuru (genel ahlaka aykirılık, şiddet ve nefret söylemi) yer alıyor mu?

4.3.İçeriklerin yapısal hataları nelerdir?

4.4.İçeriklerde görsel/metin kullanımı nasıldır?

\footnotetext{
1 Değerlendirme kriterlerinin oluşturulmasında Metin EKEN ve Hakan AYDIN tarafindan hazırlanan "Enformasyon Toplumunda Dini Bilgi Edinme: İnternet Ortamındaki Dini Enformasyonun Güvenilirliği ve Kalite Kriterleri Üzerine Bir İnceleme" isimli çalışmada yer alan ve internete uyarlanan kalite kriterlerinden faydalanılmıştır (Eken \& Aydın, 2018, ss. 898-899).
} 


\subsection{Bulgular ve Yorum}

İncelenen Instagram hesaplarının 25.10.2020 tarihinde güncellenen profil bilgileri aşağıdaki tabloda belirtilmiştir:

Tablo 1. Instagram Hesaplarinin Genel/Profil Görünümü

\begin{tabular}{|c|c|c|c|c|}
\hline Hesap Adı: $^{2}$ & Ankara'da Son Dakika $^{\text {Adana Haberleri }}$ & Samsun Medya & İstanbul'da Asayiş \\
\hline Hesap Erişim Adresi: & ankaradasondakikahaberleri & adana.haberleri & samsunmedya & istanbul.sondakika \\
\hline Takipçi Sayısı: & 483.334 & 50.562 & 31.662 & 22.430 \\
\hline Toplam Gönderi Sayısı: & 19.000 & 1.981 & 1.330 & 2.800 \\
\hline Kuruluş Tarihi: & 2018 & 2019 & Belirtilmemiş & 2018 \\
\hline Profil Açılaması: & $\begin{array}{c}\text { Ankara'daki Tüm Son } \\
\text { Dakika Haberleri }\end{array}$ & $\begin{array}{c}\text { Adana'nın Haber } \\
\text { ve Sosyal İçerik } \\
\text { Platformu }\end{array}$ & $\begin{array}{c}\text { Samsun'un İlk ve En } \\
\text { Büyük Gündem } \\
\text { Haber Medyası }\end{array}$ & İstanbul'da Asayiş \\
\hline Mavi Tik Durumu: & Yok & Yok & Yok & Yok \\
\hline
\end{tabular}

Tablo 1'de araştırmaya konu olan hesapların takipçi sayısı ve gönderileri ile ilgili bilgiler yer almaktadır. Ayrıca sayfaların profil açıklamaları, kuruluş tarihleri ile mavi tık alıp almadıkları incelenmiştir.

Bu bağlamda, incelenen hesapların oldukça fazla takipçi ve gönderi sayısına sahip olduğu belirlenmiştir. Profil açıklamalarında ise hesapların "haber" kelimesini ön plana çıkarttıkları gözlemlenmiştir. Kuruluş tarihleri yeni olan sayfaların ise Instagram'da "onaylı hesap” anlamına gelen ve hesabın gerçekliğine vurgu yapmak, orijinallik alg1sı oluşturmak için büyük önem taşıyan Mavi Tik onayına sahip olmadı̆̆1 tespit edilmiştir.

\subsubsection{Sayfaların Yayınc1 Bilgileri ve Yapısı}

Belirlenen bu kriter ile hesapların kimlik/künye bilgilerinin durumu ve sayfaların fiziki yapısı/özellikleri ölçülmüştür.

Tablo 2'de görülebileceği üzere, incelenen Instagram hesaplarının hiçbirinde tam olarak künye bilgisine yer verilmemiştir. Sayfa yöneticisinin kim olduğuna ilişkin bilgiler, iletişim bilgileri (irtibat adresi, e-mail adresi vb.), içerik üreticileri hakkında bilgiler ve yayın ilkesine ilişkin hususlar tespit edilememiştir. Künye bilgisi hukuki sorumluluk adına önemli bir bilgidir. Gazete, televizyon ve bazı haber sitelerinde olduğu gibi künye bilgilerinin açık şekilde yer alması yayımlanan içeriğin yanlış, eksik vb. bilgi olduğunda itiraz ve hukuki olarak şikâyette bulunulmasına imkân tanıması adına önem arz etmektedir.

Tablo 2. Instagram Hesaplarının Kimlik/Künye Bilgileri

\begin{tabular}{|c|c|c|c|c|c|}
\hline \multirow{2}{*}{ Hesap Adı } & \multicolumn{2}{|c|}{$\begin{array}{c}\text { Sayfalarda Künye Bilgisi ve Yayın } \\
\text { Illkelerine Yer Verilmiş mi? }\end{array}$} & \multicolumn{2}{c|}{$\begin{array}{c}\text { Instagram Hesaplarının Yayın } \\
\text { Amaçları Belirtilmiş mi? }\end{array}$} \\
\cline { 2 - 6 } & Evet & Hayır & Kısmen & Evet & Hayır \\
\hline Ankara'da Son Dakika & - & X & - & X & - \\
\hline Adana Haberleri & - & - & X & X & - \\
\hline Samsun Medya & - & X & - & X & - \\
\hline İstanbul'da Asayiş & - & X & - & X & - \\
\hline
\end{tabular}

Ayrıca hesapların profil sayfalarının üst kısmında bir cümleyle sayfa amaçlarını belirttikleri gözlemlenmiştir. Sayfalann hangi amaçla hizmet ettiğini belirten bu ifadeler kullanıcılann sayfa hakkında bir kanaate varması açısından önemlidir.

Tablo 3. Instagram Hesaplarındaki Kontrol Mekanizması

\begin{tabular}{|c|c|c|}
\hline \multirow{2}{*}{ Hesap Adı } & \multicolumn{2}{|c|}{$\begin{array}{c}\text { Sayfaların İçerik Üretiminde Kontrol } \\
\text { Süreci Uygulanıor mu? }\end{array}$} \\
\cline { 2 - 3 } & Evet & Hayır \\
\hline Ankara'da Son Dakika & - & $\mathrm{X}$ \\
\hline Adana Haberleri & - & $\mathrm{X}$ \\
\hline Samsun Medya & - & $\mathrm{X}$ \\
\hline İstanbul'da Asayiş & - & $\mathrm{X}$ \\
\hline
\end{tabular}

\footnotetext{
${ }^{2}$ Çalışmada yer verilen tablolarda Instagram adreslerinin "hesap adı" ismi kullanılmışıtır.
} 
Tablo 3'e göre incelenen Instagram hesaplarının hiçbirinde içerik üretim sürecinde uygulanan kontrol mekanizmasına ilişkin bilgiler bulunmamaktadır. Bu bakımdan, herhangi bir kontrol mekanizması/kontrol süreci uygulanmadan paylaşılan bilgi ve haberlerin de çeşitli etik problemleri bünyesinde taşıyabileceği ifade edilebilir.

Tablo 4. Instagram Hesaplarinda Okur/Kullanıc1 Yorumu

\begin{tabular}{|c|c|c|}
\hline \multirow{2}{*}{ Hesap Adı } & \multicolumn{2}{|c|}{$\begin{array}{c}\text { Sayfalarda Okurlar/Kullanıc1lar } \\
\text { Yorum Yapabiliyor mu? }\end{array}$} \\
\cline { 2 - 3 } & Evet & Hayır \\
\hline Ankara'da Son Dakika & $\mathrm{X}$ & - \\
\hline Adana Haberleri & $\mathrm{X}$ & - \\
\hline Samsun Medya & $\mathrm{X}$ & - \\
\hline İstanbul'da Asayiş & $\mathrm{X}$ & - \\
\hline
\end{tabular}

İncelenen Instagram hesaplarında okurların/kullanıcıların içeriklere yorum yapabildiği belirlenmiştir. Bu durum aynı zamanda Instagram sayfalarının takipçilerin düşüncelerini ifade etmesine imkân tanıdığını göstermektedir.

\subsubsection{Sayfaların İçerik Yapısı}

Sayfalarda yer alan içeriklerin yayınlanma biçimi incelenmiştir:

Tablo 5. Instagram Hesaplarının İçerik Paylaşım Sayısı ve Sıklığı

\begin{tabular}{|c|c|c|c|c|}
\hline \multirow{2}{*}{ Hesap Adı } & $\begin{array}{c}\text { Sayfaların 19-25 Ekim 2020 Tarihleri } \\
\text { Arasındaki Incelenen Paylaşım Sayısı }\end{array}$ & $\begin{array}{c}\text { Günde 1-3 } \\
\text { Paylaşım }\end{array}$ & $\begin{array}{c}\text { Günde 3-5 } \\
\text { Paylaşım }\end{array}$ & $\begin{array}{c}5 \text { ve Daha } \\
\text { Fazlası }\end{array}$ \\
\hline Ankara'da Son Dakika & 150 & - & - & X \\
\hline Adana Haberleri & 38 & - & X & - \\
\hline Samsun Medya & 10 & X & - & - \\
\hline İstanbul'da Asayiş & 76 & - & - & X \\
\hline Toplam & 274 & - & - & - \\
\hline
\end{tabular}

Araştırma kapsamında dört Instagram hesabının 19-25 Ekim 2020 tarihleri arasında paylaşımını yapmış olduğu toplam 274 içerik incelenmiştir. Tablo 5'de yer alan bilgilere göre en çok içeriğin Ankara'da Son Dakika ve İstanbul'da Asayiş hesaplarından paylaştığ1 görülmektedir. Ayrıca Instagram hesaplarının günlük paylaşım sıklıkları değerlendirilmiştir. Yapılan değerlendirme sonucunda en çok içerik paylaşımına sahip Ankara'da Son Dakika ve İstanbul'da Asayiş hesaplarının günde ortalama 5'den fazla içerik paylaştığ1 belirlenmiştir.

Tablo 6. Instagram Hesaplarının Reklam Kullanım Durumu

\begin{tabular}{|c|c|c|c|c|}
\hline \multirow{2}{*}{ Hesap Adı } & \multicolumn{3}{|c|}{ Sayfalarda Reklam Kullanımı } \\
\cline { 2 - 5 } & $\begin{array}{c}\text { Her } \\
\text { paylaşımda } \\
\text { reklama yer } \\
\text { verilmiştir }\end{array}$ & $\begin{array}{c}\text { Belirli } \\
\text { periyotlarda } \\
\text { reklama yer } \\
\text { verilmiştir. }\end{array}$ & $\begin{array}{c}\text { Çok nadir } \\
\text { reklam } \\
\text { verilmiştir. }\end{array}$ & $\begin{array}{c}\text { Reklama yer } \\
\text { verilmemiştir. }\end{array}$ \\
\hline Ankara'da Son Dakika & - & $\mathrm{X}$ & - & - \\
\hline Adana Haberleri & - & - & $\mathrm{X}$ & $\mathrm{X}$ \\
\hline Samsun Medya & - & - & - & $\mathrm{X}$ \\
\hline İstanbul'da Asayiş & - & - & & \\
\hline
\end{tabular}

Tablo 6'da yer alan verilerden hareketle incelenen Instagram sayfalarının reklama çoğunlukla yer vermediği gözlemlenmektedir. Sadece Ankara'da Son Dakika ve Adana Haberleri isimli hesapların kısmen reklam paylaşımında bulunduğu tespit edilmiştir. 
Tablo 7. Instagram Hesaplarında Paylaşılan İçeriklerin Konu Dağılımı

\begin{tabular}{|c|c|c|c|c|c|c|c|c|c|c|}
\hline \multirow{3}{*}{ Konular } & \multicolumn{8}{|c|}{ Hesap Adı } & \multirow{2}{*}{\multicolumn{2}{|c|}{ Toplam }} \\
\hline & \multicolumn{2}{|c|}{$\begin{array}{c}\text { Ankara'da } \\
\text { Son Dakika }\end{array}$} & \multicolumn{2}{|c|}{$\begin{array}{c}\text { Adana } \\
\text { Haberleri }\end{array}$} & \multicolumn{2}{|c|}{$\begin{array}{c}\text { Samsun } \\
\text { Medya }\end{array}$} & \multicolumn{2}{|c|}{$\begin{array}{c}\text { İstanbul'da } \\
\text { Asayiş }\end{array}$} & & \\
\hline & $\begin{array}{l}\text { Say1 } \\
\text { (f) }\end{array}$ & $\begin{array}{c}\text { Oran } \\
(\%)\end{array}$ & $\begin{array}{l}\text { Say1 } \\
(\mathrm{f})\end{array}$ & $\begin{array}{c}\text { Oran } \\
(\%)\end{array}$ & $\begin{array}{l}\text { Say1 } \\
\text { (f) }\end{array}$ & $\begin{array}{l}\text { Oran } \\
(\%)\end{array}$ & $\begin{array}{l}\text { Say1 } \\
(\mathrm{f})\end{array}$ & $\begin{array}{l}\text { Oran } \\
(\%)\end{array}$ & $\begin{array}{l}\text { Say1 } \\
(\mathrm{f})\end{array}$ & $\begin{array}{l}\text { Oran } \\
(\%)\end{array}$ \\
\hline Trafik Olayları & 8 & 5.3 & 2 & 5,3 & 0 & 0 & 13 & 17,1 & 23 & 8,4 \\
\hline Kayıp / İhbar İlanları & 0 & 0 & 0 & 0 & 0 & 0 & 2 & 2,6 & 2 & 0,7 \\
\hline Asayiş Olayları & 63 & 42 & 16 & 42,1 & 2 & 20 & 53 & 70 & 134 & 48,9 \\
\hline Siyasal Gündem & 3 & 2 & 4 & 10,5 & 3 & 30 & 0 & 0 & 10 & 3,7 \\
\hline Mizah & 0 & 0 & 0 & 0 & 0 & 0 & 1 & 1,3 & 1 & 0,3 \\
\hline Spor & 2 & 1,3 & 0 & 0 & 1 & 10 & 0 & 0 & 3 & 1,1 \\
\hline Magazin & 1 & 0,7 & 0 & 0 & 0 & 0 & 1 & 1,3 & 2 & 0,7 \\
\hline Ekonomi & 3 & 2 & 1 & 2,7 & 1 & 10 & 0 & 0 & 5 & 1,8 \\
\hline Sağllk & 23 & 15,3 & 2 & 5,2 & 1 & 10 & 2 & 2,6 & 28 & 10,2 \\
\hline Eğitim & 6 & 4 & 0 & 0 & 0 & 0 & 0 & 0 & 6 & 2,2 \\
\hline Bilim/Teknoloji & 2 & 1,3 & 0 & 0 & 0 & 0 & 0 & 0 & 2 & 0,7 \\
\hline Hava Durumu & 1 & 0,7 & 8 & 21 & 0 & 0 & 0 & 0 & 9 & 3,3 \\
\hline Reklam/İlan & 17 & 11,4 & 1 & 2,7 & 0 & 0 & 0 & 0 & 18 & 6,7 \\
\hline Diğer & 21 & 14 & 4 & 10,5 & 2 & 20 & 4 & 5,1 & 31 & 11,3 \\
\hline Toplam & 150 & 100 & 38 & 100 & 10 & 100 & 76 & 100 & 274 & 100 \\
\hline
\end{tabular}

Tablo 7'de Instagram hesaplarında paylaşılan içeriklerin konu dağılımı yer almaktadır. Bu bağlamda hesaplarda 274 paylaşım içerisinde en çok asayiş olaylanı (\%48,9) ile ilgili içeriklerin paylaşıldı̆̆ı belirlenmiştir. Bunun dışında sağlı $(\% 10,2)$, trafik olayları $(\% 8,4)$ konuları da en çok paylaşılan içerikler arasindadir.

Ayrıca yukarıdaki konu kategorisine dâhil olmayan içerikler diğer kategorisinde kodlanmıştır. Bununla birlikte incelenen Instagram hesaplarında birçok konuya ilişkin paylaşımların yapıldığı ortaya çıkmıştır.

\subsubsection{Sayfalarda Yer Alan İçeriklerin Referans/Özgünlük Durumu}

Sayfalarda yer alan içeriklerin referans/uzmanllk/özgünlük durumu ile ilgili sorgulama yapılmıştır: Tablo 8 incelendiğinde sayfaların içerik paylaşımında kaynak gösterimine çoğunlukla dikkat edilmediği görülmektedir. Ankara'da Son Dakika hesabının kısmen kaynak gösterimine önem verdiği (\%30) fakat diğer hesapların hiç kaynak göstermediği; incelenen toplam 274 paylaşım içerisinde de kaynak/yazar bilgisi yer almayan $(\% 83,2)$ içeriklerin fazla olduğu belirlenmiştir. Özellikle bilgi ve haber içeriği üreten kişi ve kurumların kaynak gösterme sorumluluğu göz önüne alındığında, incelenen hesapların kaynak göstermeden içerik paylaşması önemli bir etik problemdir.

Tablo 8. Instagram Hesaplarında Paylaşılan İçeriklerde Kaynak Gösterimi

\begin{tabular}{|c|c|c|c|c|c|c|c|c|c|c|}
\hline \multirow{3}{*}{$\begin{array}{l}\text { Sayfalarda Paylaşılan Haberlerde/Bilgilerde } \\
\text { Kaynak Gösterimi }\end{array}$} & \multicolumn{8}{|c|}{ Hesap Adı } & \multirow{2}{*}{\multicolumn{2}{|c|}{ 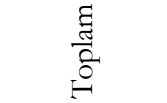 }} \\
\hline & \multicolumn{2}{|c|}{$\begin{array}{l}\text { Ankara'da } \\
\text { Son Dakika }\end{array}$} & \multicolumn{2}{|c|}{$\begin{array}{c}\text { Adana } \\
\text { Haberleri }\end{array}$} & \multicolumn{2}{|c|}{$\begin{array}{l}\text { Samsun } \\
\text { Medya }\end{array}$} & \multicolumn{2}{|c|}{$\begin{array}{c}\text { İstanbul'da } \\
\text { Asayiş }\end{array}$} & & \\
\hline & $\begin{array}{c}\text { Say1 } \\
(\mathrm{f})\end{array}$ & $\begin{array}{c}\text { Oran } \\
(\%)\end{array}$ & $\begin{array}{c}\text { Say1 } \\
(\mathrm{f})\end{array}$ & $\begin{array}{c}\text { Oran } \\
(\%)\end{array}$ & $\begin{array}{c}\text { Say1 } \\
(\mathrm{f})\end{array}$ & $\begin{array}{c}\text { Oran } \\
(\%)\end{array}$ & $\begin{array}{c}\text { Say1 } \\
\text { (f) }\end{array}$ & $\begin{array}{c}\text { Oran } \\
(\%)\end{array}$ & $\begin{array}{c}\text { Say1 } \\
(\mathrm{f})\end{array}$ & $\begin{array}{c}\text { Oran } \\
(\%)\end{array}$ \\
\hline $\begin{array}{l}\text { İçerik üreticisi/yazar/kaynak bilgisine yer } \\
\text { verilmiştir. }\end{array}$ & 45 & 30 & 1 & 2,7 & 0 & 0 & 0 & 0 & 46 & 16,8 \\
\hline $\begin{array}{l}\text { İçerik üreticisi/yazar/kaynak } \\
\text { belirlenememiştir. }\end{array}$ & 105 & 70 & 37 & 97,3 & 10 & 100 & 76 & 100 & 228 & 83,2 \\
\hline Toplam & 150 & 100 & 38 & 100 & 10 & 100 & 76 & 100 & 274 & 100 \\
\hline
\end{tabular}


Tablo 9. Instagram Hesaplarnnda Etiketleme

\begin{tabular}{|c|c|c|c|c|c|c|c|c|c|c|}
\hline \multirow{3}{*}{ Sayfalarda Etiketleme Kullanımı } & \multicolumn{8}{|c|}{ Hesap Adı } & \multirow{2}{*}{\multicolumn{2}{|c|}{ 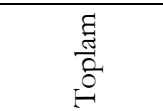 }} \\
\hline & \multicolumn{2}{|c|}{$\begin{array}{l}\text { Ankara'da } \\
\text { Son Dakika }\end{array}$} & \multicolumn{2}{|c|}{$\begin{array}{l}\text { Adana } \\
\text { Haberleri }\end{array}$} & \multicolumn{2}{|c|}{$\begin{array}{l}\text { Samsun } \\
\text { Medya }\end{array}$} & \multicolumn{2}{|c|}{$\begin{array}{l}\text { İstanbul'da } \\
\text { Asayiş }\end{array}$} & & \\
\hline & $\begin{array}{l}\text { Say1 } \\
\text { (f) }\end{array}$ & $\begin{array}{c}\text { Oran } \\
(\%)\end{array}$ & $\begin{array}{c}\text { Say1 } \\
(\mathrm{f})\end{array}$ & $\begin{array}{c}\text { Oran } \\
(\%)\end{array}$ & $\begin{array}{c}\text { Say1 } \\
(\mathrm{f})\end{array}$ & $\begin{array}{c}\text { Oran } \\
(\%)\end{array}$ & $\begin{array}{c}\text { Say1 } \\
(\mathrm{f})\end{array}$ & $\begin{array}{c}\text { Oran } \\
(\%)\end{array}$ & $\begin{array}{c}\text { Say1 } \\
(\mathrm{f})\end{array}$ & $\begin{array}{c}\text { Oran } \\
(\%)\end{array}$ \\
\hline Yanıltıcı etiketleme kullanımı mevcut. & 2 & 1,3 & 0 & 0 & 0 & 0 & 74 & 97,4 & 76 & 27,8 \\
\hline $\begin{array}{l}\text { İçeriğin kaynağına yönlendirici etiketleme } \\
\text { kullanımı mevcut. }\end{array}$ & 21 & 14 & 2 & 5,3 & 0 & 0 & 2 & 2,6 & 25 & 9,1 \\
\hline Etiketleme kullanılmamısstır. & 127 & 84,7 & 36 & 94,7 & 10 & 100 & 0 & 0 & 173 & 63,1 \\
\hline Toplam & 150 & 100 & 38 & 100 & 10 & 100 & 76 & 100 & 274 & 100 \\
\hline
\end{tabular}

Dijital ortamlarda haber ve bilgilerin alt kısımlanında kullanılan etiketleme, bir diğer adıyla hashtag, haber ve bilgi ile ilgilenebilecek kişilerin bir anahtar kelime aradıklarında bulmaları için kullanıllır. Bu etiketler, paylaşımların dikkat çekmesi ve etkileşime teşvik için kullanılmaktadır. Tablo 9'da aktarılan verilere göre Ankara'da Son Dakika, Adana Haberleri ve Samsun Medya isimli Instagram hesaplarında etiketlemenin kullanılmadı̆̆ fakat İstanbul'da Asayiş isimli hesapta yanıltıcı etiketlemelerin fazlaca yer aldığı görülmekledir.

Tablo 10. Instagram Hesaplarında Yönlendirme

\begin{tabular}{|c|c|c|c|c|c|c|c|c|c|c|}
\hline \multirow{3}{*}{ Sayfalarda Yönlendirme Kullanımı } & \multicolumn{8}{|c|}{ Hesap Ad1 } & \multirow{2}{*}{\multicolumn{2}{|c|}{ 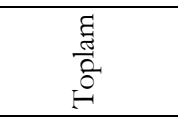 }} \\
\hline & \multicolumn{2}{|c|}{$\begin{array}{l}\text { Ankara'da } \\
\text { Son Dakika }\end{array}$} & \multicolumn{2}{|c|}{$\begin{array}{l}\text { Adana } \\
\text { Haberleri }\end{array}$} & \multicolumn{2}{|c|}{ Samsun Medya } & \multicolumn{2}{|c|}{$\begin{array}{l}\text { İstanbul'da } \\
\text { Asayiş }\end{array}$} & & \\
\hline & $\begin{array}{l}\text { Say1 } \\
\text { (f) }\end{array}$ & $\begin{array}{c}\text { Oran } \\
(\%)\end{array}$ & $\begin{array}{c}\text { Say1 } \\
(\mathrm{f})\end{array}$ & $\begin{array}{c}\text { Oran } \\
(\%)\end{array}$ & $\begin{array}{l}\text { Say1 } \\
(\mathrm{f})\end{array}$ & $\begin{array}{l}\text { Oran } \\
(\%)\end{array}$ & $\begin{array}{c}\text { Say1 } \\
\text { (f) }\end{array}$ & $\begin{array}{l}\text { Oran } \\
(\%)\end{array}$ & $\begin{array}{c}\text { Say1 } \\
(\mathrm{f})\end{array}$ & $\begin{array}{c}\text { Oran } \\
(\%)\end{array}$ \\
\hline Haber sitelerine yönlendirme mevcuttur. & 0 & 0 & 0 & 0 & 0 & 0 & 0 & 0 & 0 & 0 \\
\hline $\begin{array}{l}\text { Sosyal medya platformlarına } \\
\text { vönlendirme mevcuttur. }\end{array}$ & 22 & 14,7 & 1 & 2,6 & 0 & 0 & 1 & 1.3 & 24 & 8,8 \\
\hline Kişisel bloglara yönlendirme mevcuttur. & 0 & 0 & 0 & 0 & 0 & 0 & 0 & 0 & 0 & 0 \\
\hline $\begin{array}{l}\text { Reklam sayfalarına yönlendirme } \\
\text { mevcuttur. }\end{array}$ & 0 & 0 & 0 & 0 & 0 & 0 & 0 & 0 & 0 & 0 \\
\hline Diğer sayfalara yönlendirme mevcuttur. & 1 & 0,7 & 0 & 0 & 1 & 10 & 1 & 1.3 & 3 & 1,1 \\
\hline $\begin{array}{l}\text { Herhangi bir yönlendirme } \\
\text { bulunmamaktadır. }\end{array}$ & 127 & 84,6 & 37 & 97,4 & 9 & 90 & 74 & 97,4 & 247 & 90,1 \\
\hline Toplam & 150 & 100 & 38 & 100 & 10 & 100 & 76 & 100 & 274 & 100 \\
\hline
\end{tabular}

Tablo 10'da görülebileceği üzere, Instagram hesaplarında paylaşılan içerikler ile ilgili çoğunlukla yönlendirmenin yapılmadığı belirlenmiştir. Sadece Ankara'da Son Dakika isimli hesabın, paylaşımların bir kısmında sosyal medya platformlarına $(\% 14,7)$ yönlendirme yaptığı tespit edilmiştir.

Tablo 11. Instagram Hesaplarındaki İçeriklerin Özgünlük Durum

\begin{tabular}{|c|c|c|c|c|c|c|c|c|c|c|}
\hline \multirow{3}{*}{$\begin{array}{l}\text { Sayfalarda Etiketleme/Yönlendirme } \\
\text { Kullanımı }\end{array}$} & \multicolumn{8}{|c|}{ Hesap Adı } & \multirow{2}{*}{\multicolumn{2}{|c|}{ 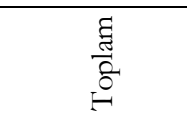 }} \\
\hline & \multicolumn{2}{|c|}{$\begin{array}{l}\text { Ankara'da } \\
\text { Son Dakika }\end{array}$} & \multicolumn{2}{|c|}{$\begin{array}{l}\text { Adana } \\
\text { Haberleri }\end{array}$} & \multicolumn{2}{|c|}{$\begin{array}{l}\text { Samsun } \\
\text { Medya }\end{array}$} & \multicolumn{2}{|c|}{$\begin{array}{l}\text { İstanbul'da } \\
\text { Asayiş }\end{array}$} & & \\
\hline & $\begin{array}{l}\text { Say1 } \\
(\mathrm{f})\end{array}$ & $\begin{array}{c}\text { Oran } \\
(\%)\end{array}$ & $\begin{array}{l}\text { Say1 } \\
(\mathrm{f})\end{array}$ & $\begin{array}{c}\text { Oran } \\
(\%)\end{array}$ & $\begin{array}{c}\text { Say1 } \\
\text { (f) }\end{array}$ & $\begin{array}{l}\text { Oran } \\
(\%)\end{array}$ & $\begin{array}{c}\text { Say1 } \\
\text { (f) }\end{array}$ & $\begin{array}{l}\text { Oran } \\
(\%)\end{array}$ & $\begin{array}{l}\text { Say1 } \\
(\mathrm{f})\end{array}$ & $\begin{array}{c}\text { Oran } \\
(\%)\end{array}$ \\
\hline Özgün Paylaşım & 24 & 16 & 5 & 13,2 & 2 & 20 & 6 & 7,9 & 37 & 13,6 \\
\hline Derleme İçerik & 0 & 0 & 0 & 0 & 0 & 0 & 8 & 10,5 & 8 & 2,9 \\
\hline Anonim Üretim & 94 & 62,7 & 32 & 84,2 & 8 & 80 & 62 & 81,6 & 196 & 71,5 \\
\hline Alınt Aktarım & 32 & 21,3 & 1 & 2,6 & 0 & 0 & 0 & 0 & 33 & 12 \\
\hline Toplam & 150 & 100 & 38 & 100 & 10 & 10 & 76 & 100 & 274 & 100 \\
\hline
\end{tabular}

Tablo 11 ile Instagram hesaplarında yer alan içeriklerin özgünlük durumu ölçülmüştür. Yapılan inceleme sonucunda ise Instagram hesaplarının içeriklerinin çoğunlukla özgün olmadığ1 belirlenmiştir. Özellikle kaynağ1 ve üreticisi belirsiz anonim üretimlerin Instagram hesaplarında fazlaca paylaşıldığ1 $(\% 71,5)$, bununla birlikte farklı yerlerde üretilen içeriklerin alıntı verilerek paylaşıldığı (\%12) tespit edilmiştir. Bu bağlamda haber ve medya şirketi etiketi ile paylaşım yapan Instagram hesaplarının özgün içerik üretme ve paylaşma noktasında yeterince zayıf olduğu ifade edilebilir 


\subsubsection{Sayfalarda Yer Alan İçeriklerin Nitelikleri}

Sayfalardaki paylaşımların içerik özellikleri değerlendirilmiştir:

Tablo 12. Instagram Hesaplarındaki İçeriklerde Haber ve Reklam Ayrımı

\begin{tabular}{|c|c|c|c|c|c|c|c|c|c|c|}
\hline \multirow{3}{*}{$\begin{array}{l}\text { Sayfalarda Yer Alan İçeriklerde } \\
\text { Haber-Reklam Ayrımı }\end{array}$} & \multicolumn{8}{|c|}{ Hesap Adı } & \multirow{2}{*}{\multicolumn{2}{|c|}{ 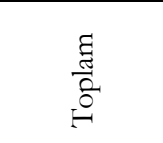 }} \\
\hline & \multicolumn{2}{|c|}{$\begin{array}{l}\text { Ankara'da } \\
\text { Son Dakika }\end{array}$} & \multicolumn{2}{|c|}{$\begin{array}{l}\text { Adana } \\
\text { Haberleri }\end{array}$} & \multicolumn{2}{|c|}{$\begin{array}{l}\text { Samsun } \\
\text { Medya }\end{array}$} & \multicolumn{2}{|c|}{$\begin{array}{l}\text { İstanbul'da } \\
\text { Asayiş }\end{array}$} & & \\
\hline & $\begin{array}{l}\text { Say1 } \\
(\mathrm{f})\end{array}$ & $\begin{array}{c}\text { Oran } \\
(\%)\end{array}$ & $\begin{array}{l}\text { Say1 } \\
(\mathrm{f})\end{array}$ & $\begin{array}{c}\text { Oran } \\
(\%)\end{array}$ & $\begin{array}{l}\text { Say1 } \\
\text { (f) }\end{array}$ & $\begin{array}{l}\text { Oran } \\
(\%)\end{array}$ & $\begin{array}{l}\text { Say1 } \\
\text { (f) }\end{array}$ & $\begin{array}{l}\text { Oran } \\
(\%)\end{array}$ & $\begin{array}{c}\text { Say1 } \\
(f)\end{array}$ & $\begin{array}{l}\text { Oran } \\
(\%)\end{array}$ \\
\hline Haber ve reklam bir arada verilmisstir. & 0 & 0 & 0 & 0 & 0 & 0 & 0 & 0 & 0 & 0 \\
\hline Haber reklam ayrımı yapılmıştır. & 16 & 10,7 & 1 & 2,6 & 0 & 0 & 0 & 0 & 17 & 6,3 \\
\hline Reklam yer almamaktadır. & 134 & 89,3 & 37 & 97,4 & 10 & 100 & 76 & 100 & 257 & 93,7 \\
\hline Toplam & 150 & 100 & 38 & 100 & 10 & 100 & 76 & 100 & 274 & 100 \\
\hline
\end{tabular}

Tablo 12 ile Instagram hesaplarında haber ve reklam ayrımının yapılıp yapılmadığı incelenmiştir. Araştırma sonucunda sayfaların çoğunlukla reklam paylaşmadı̆̆ı, reklam paylaşımında da haber / reklam ayrımına dikkat edildiği belirlenmiştir.

Tablo 13. Instagram Hesaplarında Suç Unsuru İçeren Paylaşımlar

\begin{tabular}{|c|c|c|c|c|c|c|c|c|c|c|}
\hline \multirow{3}{*}{$\begin{array}{l}\text { Sayfalarda Genel Ahlaka Aykırı, Şiddet ve } \\
\text { Nefret Söylemi İçeren Paylaşımlar }\end{array}$} & \multicolumn{8}{|c|}{ Hesap Adı } & \multirow{2}{*}{\multicolumn{2}{|c|}{ 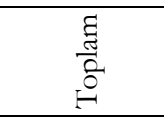 }} \\
\hline & \multicolumn{2}{|c|}{$\begin{array}{c}\text { Ankara'da } \\
\text { Son Dakika }\end{array}$} & \multicolumn{2}{|c|}{$\begin{array}{c}\text { Adana } \\
\text { Haberleri }\end{array}$} & \multicolumn{2}{|c|}{$\begin{array}{c}\text { Samsun } \\
\text { Medya }\end{array}$} & \multicolumn{2}{|c|}{$\begin{array}{l}\text { İstanbul'da } \\
\text { Asayiş }\end{array}$} & & \\
\hline & $\begin{array}{c}\text { Say1 } \\
(\mathrm{f})\end{array}$ & $\begin{array}{c}\text { Oran } \\
(\%)\end{array}$ & $\begin{array}{c}\text { Say1 } \\
\text { (f) }\end{array}$ & $\begin{array}{c}\text { Oran } \\
(\%)\end{array}$ & $\begin{array}{c}\text { Say1 } \\
(\mathrm{f})\end{array}$ & $\begin{array}{c}\text { Oran } \\
(\%)\end{array}$ & $\begin{array}{l}\text { Say1 } \\
\text { (f) }\end{array}$ & $\begin{array}{l}\text { Oran } \\
(\%)\end{array}$ & $\begin{array}{c}\text { Say1 } \\
(\mathrm{f})\end{array}$ & $\begin{array}{c}\text { Oran } \\
(\%)\end{array}$ \\
\hline $\begin{array}{l}\text { Müstehcen veya şiddet içeren içerikler } \\
\text { mevcuttur. }\end{array}$ & 0 & 0 & 0 & 0 & 0 & 0 & 7 & 9,2 & 7 & 2,5 \\
\hline Nefret söylemi kullanılmaktadır. & 0 & 0 & 0 & 0 & 0 & $\sigma$ & 0 & 0 & 0 & 0 \\
\hline $\begin{array}{l}\text { Herhangi bir suç unsuru yer } \\
\text { almamaktadır. }\end{array}$ & 150 & 100 & 38 & 100 & 10 & 100 & 69 & 90,8 & 267 & 97,5 \\
\hline Toplam & 150 & 100 & 38 & 100 & 10 & 100 & 76 & 100 & 274 & 100 \\
\hline
\end{tabular}

Tablo 13 ile Instagram hesaplarındaki paylaşımlarda genel ahlaka aykırılık, şiddet ve nefret söylemi gibi suç unsuru barındıran içeriklere yer verilip verilmediği sorgulanmıştır. İnceleme sonucunda Instagram hesaplarının belirtilen tarih aralığında herhangi bir suç unsuru içeren paylaşıma yer vermediği belirlenmiştir. Sadece İstanbul'da Asayiş isimli hesabın müstehcen ve şiddet unsuru içeren paylaşımlar yaptı̆̆1 tespit edilmiştir.

Tablo 14. Instagram Hesaplarında İçeriklerin Yapısal Hataları

\begin{tabular}{|c|c|c|c|c|c|c|c|c|c|c|}
\hline \multirow{3}{*}{$\begin{array}{l}\text { Sayfalardaki İçeriklerde } \\
\text { Yer Alan Hatalar }\end{array}$} & \multicolumn{8}{|c|}{ Hesap Adı } & \multirow{2}{*}{\multicolumn{2}{|c|}{ 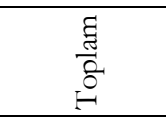 }} \\
\hline & \multicolumn{2}{|c|}{$\begin{array}{c}\text { Ankara'da } \\
\text { Son Dakika }\end{array}$} & \multicolumn{2}{|c|}{$\begin{array}{c}\text { Adana } \\
\text { Haberleri } \\
\end{array}$} & \multicolumn{2}{|c|}{$\begin{array}{c}\text { Samsun } \\
\text { Medya }\end{array}$} & \multicolumn{2}{|c|}{$\begin{array}{c}\text { İstanbul'da } \\
\text { Asayiş }\end{array}$} & & \\
\hline & $\begin{array}{c}\text { Say1 } \\
\text { (f) }\end{array}$ & $\begin{array}{c}\text { Oran } \\
(\%)\end{array}$ & $\begin{array}{c}\text { Say1 } \\
\text { (f) }\end{array}$ & $\begin{array}{c}\text { Oran } \\
(\%)\end{array}$ & $\begin{array}{c}\text { Say1 } \\
\text { (f) }\end{array}$ & $\begin{array}{l}\text { Oran } \\
(\%)\end{array}$ & $\begin{array}{c}\text { Say1 } \\
\text { (f) }\end{array}$ & $\begin{array}{c}\text { Oran } \\
(\%)\end{array}$ & $\begin{array}{l}\text { Say1 } \\
(\mathrm{f})\end{array}$ & $\begin{array}{c}\text { Oran } \\
(\%)\end{array}$ \\
\hline İmla ve Nokta & 53 & 35,3 & 13 & 34,2 & 6 & 60 & 10 & 13,2 & 82 & 29,9 \\
\hline İmla ve Noktalama Hatası Yoktur. & 97 & 64,7 & 25 & 65,8 & 4 & 40 & 66 & 86,8 & 192 & 70,1 \\
\hline Toplam & 150 & 100 & 38 & 100 & 10 & 100 & 76 & 100 & 274 & 100 \\
\hline
\end{tabular}

Tablo 14 ile Instagram hesaplarında paylaşılan bilgi ve haberlerin imla ve noktalama kurallarına uygunluk durumu incelenmiştir. Yapılan inceleme sonucunda hesapların paylaşımlarında imla ve noktalama kurallarına uyulmaya çalışıldığı $(\% 70,1)$ fakat bazı paylaşımlarda da imla ve noktalama hatalanının olduğu $(\% 29,9)$ belirlenmiştir. 
Tablo 15. Instagram Hesapları İçeriklerinde Görsel / Metin Kullanımı

\begin{tabular}{|c|c|c|c|c|c|c|c|c|c|c|}
\hline \multirow{3}{*}{$\begin{array}{l}\text { Sayfalardaki İçeriklerde Görsel / } \\
\text { Metin Kullanımı }\end{array}$} & \multicolumn{8}{|c|}{ Hesap Adı } & \multirow{2}{*}{\multicolumn{2}{|c|}{$\overrightarrow{0} \frac{0}{0}$ ह }} \\
\hline & \multicolumn{2}{|c|}{$\begin{array}{l}\text { Ankara'da } \\
\text { Son Dakika }\end{array}$} & \multicolumn{2}{|c|}{$\begin{array}{l}\text { Adana } \\
\text { Haberleri }\end{array}$} & \multicolumn{2}{|c|}{$\begin{array}{l}\text { Samsun } \\
\text { Medya }\end{array}$} & \multicolumn{2}{|c|}{$\begin{array}{l}\text { İstanbul'da } \\
\text { Asavis }\end{array}$} & & \\
\hline & $\begin{array}{c}\text { Say1 } \\
(\mathrm{f})\end{array}$ & $\begin{array}{c}\text { Oran } \\
(\%)\end{array}$ & $\begin{array}{c}\text { Say1 } \\
(\mathrm{f})\end{array}$ & $\begin{array}{c}\text { Oran } \\
(\%)\end{array}$ & $\begin{array}{l}\text { Say1 } \\
(\mathrm{f})\end{array}$ & $\begin{array}{c}\text { Oran } \\
(\%)\end{array}$ & $\begin{array}{l}\text { Say1 } \\
\text { (f) }\end{array}$ & $\begin{array}{c}\text { Oran } \\
(\%)\end{array}$ & $\begin{array}{c}\text { Say1 } \\
(\mathrm{f})\end{array}$ & $\begin{array}{c}\text { Oran } \\
(\%)\end{array}$ \\
\hline Sadece görsel kullanılmıştır. & 3 & 2 & 0 & 0 & 0 & 0 & 0 & 0 & 3 & 1,1 \\
\hline Sadece metin kullanılmıştır. & 0 & 0 & 0 & 0 & 0 & 0 & 0 & 0 & 0 & 0 \\
\hline $\begin{array}{l}\text { Görsel / metin bir arada } \\
\text { kullanılmiştır. }\end{array}$ & 147 & 98 & 38 & 100 & 10 & 100 & 76 & 100 & 271 & 98,9 \\
\hline Toplam & 150 & 100 & 38 & 100 & 10 & 100 & 76 & 100 & 274 & 100 \\
\hline
\end{tabular}

Tablo 15'te de görülebileceği üzere Instagram hesaplarının bütün içeriklerinde görsel kullanımına önem verdiği tespit edilmiştir. Görsel içermeyen paylaşımların olmadığı ve paylaşımların neredeyse çoğunluğunda görsellerin ve metinlerin birlikte kullanıldığ1 $(\% 98,9)$ ortaya çıkmıştır.

\section{Genel Değerlendirme}

Sosyal medya haberciliğindeki etik problemleri tespit edebilmek amacıyla yapılan araşturma kapsamında öne çıkan sonuçları şu şekilde ifade etmek mümkündür:

1.Medya/haber şirketi etiketi ile yayın yapan Instagram hesaplarının olukça fazla takipçi sayısına ve içerik paylaşımına sahip olduğu belirlenmiştir.

2.Instagram hesaplarının yayıncı bilgileri ve sayfa yapılannın incelenmesi sonucunda şu veriler ortaya ç1kmiştır:

-Sayfalarda künye bilgilerinin ve yayın ilkelerinin yer almadı̆̆1 tespit edilmiştir.

-Sayfaların yayın amaçlarının haber/bilgi aktarmak olduğu yayın amaçlarında belirtilmiştir.

-Instagram hesaplarındaki paylaşımlann herhangi bir kontrol mekanizmasından geçmeden paylaşıldığı ortaya çıkmıştır.

-Sayfaların okur/kullanıcı yorumuna izin verdiği gözlemlenmiştir.

3.Instagram hesaplarının içerik yapısı ile ilgili şu bulgulara ulaşılmıştır:

-Genellikle her gün birkaç paylaşım yaptıkları ve çoğunlukla reklam kullanmadıkları tespit edilmiştir.

-Paylaşımların içeriklerinde ise konu dağılımının çok çeşitli olduğu, bununla birlikte asayiş olaylarının, trafik olaylarının ve sağlık ile ilgili gelişmelerin en çok paylaşılan konu başlıkları olduğu belirlenmiştir.

4.Instagram hesaplarında yer alan içeriklerin referans/özgünlük durumu ile ilgili şu veriler ortaya çıkmıştur:

-Sayfaların paylaşımlarında büyük oranda kaynak kullanılmadı̆̆ı gözlemlenmiştir.

-Paylaşımların dikkat çekebilmesini sağlamak amacıyla etiketleme (hashtag) yöntemine başvurulmadı̆̆ı, bununla birlikte sayfalarda yönlendirme yapılmamasına dikkat edildiği, sadece bazı sayfaların sosyal medya platformlarına yönlendirme yapıldı̆̆ı belirlenmiştir.

-Instagram hesaplarının paylaşımlanındaki içeriklerin özgünlük durumunun zayıf olduğu, genellikle kaynağı belirtilmeyen anonim üretimlerin, alıntı aktarımlann paylaşıldığı ortaya çıkmıştır.

5.Instagram hesaplarında yer alan içeriklerin özellikleri ile ilgili yapıllan sorgulama neticesinde aşağıdaki sonuçlar elde edilmiştir:

-Sayfaların paylaşımlarında suç unsuru (genel ahlaka aykırılık, şiddet içerikli ve nefret söylemi) barındıran içeriklerin oldukça az olduğu gözlemlenmiştir.

-Kısmen de olsa sayfaların içerik oluştururken noktalama ve imla hatalarında bulundukları belirlenmiştir. İmla ve noktalama hatalarının büyük bir kısmı sayfaların kendi ürettiği az sayıdaki özgün içeriklerde görülmüştür.

-İçeriklerin çoğunluklar görsel malzemeler kullanılarak paylaşıldığı tespit edilmiştir.

\section{Tartışma ve Sonuç}

Sosyal medyayı kullanan insanların sayısındaki ciddi artıs, haber mecralarının bu platformlara kaymasına sebep olurken, birçok profesyonel haber kurumu, bu yeni medya ortamlarından izleyici ve okuyucularına bilgi sunmaktadır. Profesyonel anlamda sosyal medya haberciliğini kurumsal bir şekilde yapan ve etik 
kodlara önem veren sayfaların yanında, bireysel ve herhangi bir kurumsallık bilgisinin olmadığı sayfalar aracıllı̆ı ile de habercilik yapılmaktadır.

Çalışma kapsamında yapılan araştırma bulguları da göstermektedir ki medya profesyonellerinin dışında içerik üreten sosyal medya sayfaları birçok etik problemi ihtiva etmektedir. Bu problemleri şu başlıklarla özetlemek mümkündür:

Güvenilirlike Eksikliği: Sosyal medya hesaplarında paylaşılan içeriklerin üreticisi, kaynağı, üreten kişinin uzmanlık/eğitim durumu bilinmemektedir. Bununla birlikte sayfaların, içerik paylaşan kişilerin kim/hangi kurum veya yapı olduğuna yönelik bilgilendirme bulunmamaktadır. Sayfaların künye bilgisinin olmaması da bu problemleri daha da artırmaktadır. Bu problemler de haberlerin/bilgilerin eksik, yanlıss, yanıltıcı veya manipüle amaçlı paylaşımlar olabileceğine yönelik sorgulamaya sebep olmaktadır.

Kontrol Eksikliğgi: Paylaşılan içeriklerin kontrol mekanizmasından geçmemesi, haberlerin/bilgilerin editöryal problemler taşıyabileceğini göstermektedir. Ayrıca kontrol mekanizmasının yokluğu paylaşılan içeriklerin teyit edilip edilmediğine, araştırma/sorgulama süzgecinden geçip geçmediğine ilişkin soru işaretlerini artırmaktadır.

Özgün İerik Yoksunluğg: Sayfalarda yer alan paylaşımların büyük çoğunluğunun anonim, yani kaynağ1, üreticisi belirsiz olan veya başka kaynaklardan alınan alıntı, telifsiz içerikler olduğu tespit edilmiştir. Dolayısıyla bu durum da, değer katıcı olmayan, kopyala yapıştır usulü ile içerik üreten bu hesapların özgünlüğünü, haberciliğe katkısını tartışmaya açmaktadır.

Kurumsal olmayan, takipçi sayısı fazla olan ve medya/haber şirketi etiketi ile yayıncılık yapan bağımsız sosyal medya hesaplarının belirli tarih aralığında incelenen paylaşımlarında yukarıda bahsedilen problemler tespit edilmiştir. Özellikle benzeri şekilde yayın yapan hesaplar sebebiyle habercilikteki etik meselelerin dijitalleşme ile artabilen bir görünüme sahip olduğunu ifade etmek mümkündür.

Bu bağlamda, içerik üretiminde kimlik ve veri doğrulama sisteminin geliştirilmesi, sahte olan veya kontrol edilmemiş içerik ve hesapların tespit edilebilmesi, kopyala yapışır usulü ile içerik üretiminin düzenlenmesi ve insanların bilgi alma/haberleşme sürecini zedeleyecek, bilgi kirliliğine yol açacak zararlı içeriklerin resmi kurumlarca denetlenmesi ve belirtilen problemler sebebiyle okuyucuların, takipçilerin haberleşme/bilgi edinme sürecinde daha dikkatli olması gerekmektedir.

\section{Extended Abstract}

In the process where new media users are not only consumers but also producers, they can provide information flow over internet networks extremely quickly and communicate with each other, social media platforms provide important opportunities for sharing and spreading information. However, the easy production of news via social media networks and their free and without any supervision has brought along some problems. In the literature, it is possible to come across studies dealing with the role of social media tools (especially in the example of Facebook and Twitter) in the process of information acquisition / communication and journalism practices transformed by digitalization.

However, it is noteworthy that there are few studies on ethical problems encountered in the digitalization process in line with the media / new media and ethical relationality and that there are no studies that discuss the ethical issue in social media journalism in the example of Instagram. In this perspective, in the study aiming to question the journalism activity on social media through ethical issues; First of all, the concept of new media, social media journalism and a conceptual framework was created in line with ethical problems in journalism.

Along with the theoretical infrastructure created regarding ethical problems that need to be considered in the digitalization process and social media journalism; in order to measure the use of ethical elements in social media journalism, four Instagram accounts that are not affiliated with a specific institution or business or for which information about these issues could not be confirmed in Instagram application, whose usage rate has increased in recent years and there is no control mechanism in content production / sharing, were analyzed by content analysis method.

Within the scope of the research, 112 Instagram accounts in Boomsocial (social media monitoring and reporting program) in September-October 2020 and listed in the news sites tab in the press category were evaluated. As a result of the evaluation, four Instagram accounts with the access address 
"ankaradasondakikahaberleri”, "adana.haberleri", "samsunmedya", "istanbul.sondakika" that publish with media / news company tags and have content that will allow research and have the most followers were examined. It is possible to express the prominent results within the scope of the research as follows:

1.It was determined that Instagram accounts broadcasting with the media / news company tag have quite a number of followers and content sharing.

2.As a result of examining the publisher information and page structures of Instagram accounts, the following data emerged:

-It was determined that the pages do not contain the information about the title and the publication principles.

-It was stated in the publication purposes that the publication purposes of the pages were to convey news / information.

-It was revealed that the shares on Instagram accounts are shared without going through any control mechanism.

-It was observed that the pages allow reader / user comment.

3.The following findings were obtained regarding the content structure of Instagram accounts:

-It was found that they usually post a few posts every day and mostly don't use ads.

-It was determined that the content of the posts, on the other hand, had a wide variety of topics, however, public security incidents, traffic incidents and health-related developments were the most shared topics.

4.The following data was emerged regarding the reference / originality status of the content in Instagram accounts:

-It was observed that the pages were not used to a large extent in their sharing.

-It was determined that the method of tagging (hashtag) was not used in order to make the shares attract attention, however, attention was paid not to redirect the pages, and only some pages redirected to social media platforms.

-It turned out that the uniqueness of the content on Instagram accounts is weak, and anonymous productions and citations are shared.

5.As a result of the query about the features of the content in Instagram accounts, the following results were obtained:

-It was observed that the content of the pages containing criminal elements (contrary to general morality, violent and hate speech) was very rare.

-It was determined that the pages had punctuation and spelling mistakes while creating content, even if only partially.

-It was determined that the content was mostly shared using visual materials.

However, the research findings made within the scope of the study also show that social media pages that produce content other than media professionals contain many ethical problems. It is possible to summarize these problems under the following headings:

Lack of credibility: The producer, source, and expertise / education status of the producer of the content shared on social media accounts are unknown. However, the pages do not provide information about whom / which institution or structure the people who share the content are. The fact that the pages do not have the information about their identification increases these problems even more. These problems lead to inquiries about whether the news / information may be incomplete, inaccurate, misleading or manipulating.

Lack of control: The fact that the shared content does not pass through the control mechanism indicates that the news / information may have editorial problems. In addition, the absence of a control mechanism raises questions about whether the shared contents are verified and whether they pass the search / inquiry filter.

Lack of Original Content: It was determined that the majority of the posts on the pages were anonymous, meaning that the source and producer were unclear, or that they were quoted or royalty-free from other sources. Therefore, this situation brings to discussion the originality and contribution of these accounts, which do not add value and produce content by copy-paste method, to journalism. 


\section{Kaynakça}

Aydın, H. ve Yazıcı, F. (2020). Dijital Çağda Bilginin Doğruluğu ve Sahte Haber. Yeni Medya Cağında Popüler Dijital Sorunlar içinde (ss. 103-128). Ankara: Nobel. 58-69.

Aydoğan, F. ve Kırık, A. M. (2012). Alternatif Medya Olarak Yeni Medya, Akdeniz İletişim Dergisi, (18),

Bayrak, T. (2017). Sosyal Medyada Dijital Etik: Twitter'da Şiddet İçerikli İletilerin Íncelenmesi., Yeni Medya Elektronik Dergisi, 1(1), 32-46.

Bayraktutan, G. (2012). Yeni Medyanın Etik Sorunları Üzerine Bir Değerlendirme. D. Yengin (Ed.), Yeni Medya Ve... içinde (ss. 237-258). İstanbul: Anahtar Kitaplar.

Binark, M. ve Löker, K. (2011). Sivil Toplum Örgütleri İcin Bilişim Rebberi. Ankara: Sivil Toplum Geliştirme Merkezi.

Binark, M. ve Bayraktutan, G. (2013). Ayın Karanlı Yüzü: Yeni Medya ve Etik. İstanbul: Kalkedon.

Binark, M. (2014). Yeni Medya Calısmalarında Araștırma Yöntem ve Teknikleri. İstanbul: Ayrıntı Yayınları.

Creswell, J.W. (2019). Eğitim Arastırmalar. İstanbul: Edam Yayınlan.

Çetinkaya, A. (2019). Çevrimiçi Gazetelerin Instagram Üzerinden Haber Paylaşımı. Kritik İletişim Calısmalar Dergisi, 1, (2), 1-28.

Devran, Y. ve Özcan, Ö. F. (2017). Habercilikte Hegemonya Mücadelesi: Yurttaş Gazeteciliği: Fırsat m1 Tehdit mi?, Global Media Journal TR Edition, 7 (14), 150-173.

Dilmen, N. (2007). Yeni Medya Kavramı Çerçevesinde İnternet Günlükleri-Bloglar ve Gazeteciliğe Yansimalan1, Marmara İletisim Dergisi.

Eken, M. ve Aydın, H. (2018). Enformasyon Toplumunda Dini Bilgi Edinme: İnternet Ortamındaki

Dini Enformasyonun Güvenilirliği ve Kalite Kriterleri Üzerine Bir İnceleme, Uluslatarası Sosyal Araștırmalar

Dergisi, Cilt: 11 Say1: 58 Ağustos 2018, 894-906.

Erdoğan, İ. (2012). Pozitivist Metodoloji ve Ötesi Arastırma Tasarmlar Nitelikesel ve Istatiksel Yöntemler.

Ankara: Erk Yayınları.

Erdoğan, İlker. (2014). Yeni Medya Gazeteciliğinde Etik Bir Pradigma Belirlemenin Kapsamı ve Sinırlan. E. B. Akca (Ed.). Yeni Medya, Yeni Pratikler, Yeni Olanaklar içinde (ss. 79-102). Kocaeli: Umuttepe.

Geray, H. (2014). İletişim Alanından Örneklerle Toplumsal Araştırmalarda Nicel ve Nitel Yöntemlere Giriş.

Kocaeli: Umuttepe Yayınları.

Kalan, Ö. (2016). Yeni Medyada Reklam ve Etik Sorunlar. Atatürk İletişim Dergisi, 10 (1), 71-89.

Kennedy, G. (2015). Social Media: Master Social Media Marketing - Facebook, Twitter, YouTube Instagram. ABD: CreateSpace Independent Publishing Platform.

Kurt, H. (2014). Gazetecilik Pratiği ve Sosyal Medya Journalism Practice and Social Media. Gaz̧iantep University Journal of Social Sciences, 13 (4), 821-835.

Neuman, W. L. (2014). Toplumsal Arastırma Yöntemleri 2. (Çev. Sedef Özge) Ankara: Yayın Odas1 Yayınlar1.

Özcan, E. Yeni Medya ve Etik: Türkiye'de İnternet Haberciliğinde Karşılaş1lan Etik Sorunlar Üzerine

Bir Araşturma. Marmara Üniversitesi Yüksek Lisans Tezi. 2019.

Öztürk, Ş. (2015). Sosyal Medyada Etik Sorunlar. Selçuk İletişim Dergisi, 9 (1): 287-311.

Taşkıran, İ. ve Kırık, A. M. (2016). Gazetecilerin Sosyal Medyayı Haber Kaynağı Olarak Kullanımı: Medya Profesyonellerinin Bakış Açılarını Tespit Etmeye Yönelik Bir Araşurma. Intermedia International ejournal, 1 (3), 213-213. doi:10.21645/intermedia.2016319269

Timisi, N. (2003). Yeni İletişim Teknolojileri ve Demokrasi. Ankara: Dost Kitabevi.

Türkiye Gazeteciler Cemiyeti, (2020). Türkiye Gazetecileri Hak ve Sorumluluk Bildirgesi. Erişim Adresi: https://www.tgc.org.tr/bildirgeler/t\% $\%$ C3\%BCrkiye-gazetecilik-hak-ve-sorumluluk-bildirgesi.html. Erișim Tarihi: 11.10 .2020

Uzun, R. (2007). İletişim Etiği Sorunlar ve Sorumluluklar. Ankara: Gazi Üniversitesi İletişim Fakültesi

İnternet Siteleri:

Boomsocial, https:/ /www.boomsocial.com/, Erişim Tarihi: 01.10.2020. Erişim Adresi: https://www.boomsocial.com/Instagram/UlkeSektor/turkey/basin-yayin/haber-siteleri?page=1

Datareportal, https://datareportal.com/, Erişim Tarihi: 05.10.2020. Erişim Adresi: 
https://datareportal.com/reports/digital-2020-turkey

Türk Dil Kurumu Sözlükleri. (2020). Erişim Tarihi: 20.09.2020. Erişim Adresi:

https://sozluk.gov.tr/ adresinden erişildi. 